\title{
THE ULTRASTRUCTURE OF TASTE BUDS IN THE NEWBORN CAT
}

\author{
F. TICHÝ \\ Department of Anatomy, Histology and Embryology \\ University of Veterinary and Pharmaceutical Sciences \\ 61242 Brno, Czech Republic
}

Received August 15, 1992

\begin{abstract}
Tichý F.: The ultrastructure of taste buds in the newborn cat. Acta vet. Brno, 63, 1994: 49-54.

The ultrastructure of taste buds on circumvallate papillae was studied in one-day-old kittens. Attention was paid to the occurrence, localization and presence of organelles in dark, light and receptor cells, formation of the porus gustatorius and occurence of intragemmal nerve fibres and their relation to the three cell types of the bud.

At the time after birth, the feline taste bude contained dark, light and receptor cells. All three cell types had a high amount of filaments in the cytoplasm. In the dark cells, secretory granules and dark substance in the porus gustatorius were seen only occasionally. Both dark and light vesicles in the cytoplasm were only rare findings in the receptor cells. The apical portions of bud cells did not terminate as microvilli and never came to level with the epithelial surface. Infrequent intragemmal nerve fibres were in contact with all bud cell types.
\end{abstract}

\section{Taste bud, porus gustatorius, nerve fibre, domestic cat, ultrastructure}

The ultrastructure of taste buds has been studied in various amphibian species (Farbman and Yonkers 1971), laboratory animals (Farbman 1965a; Murray et al. 1969, 1972; Fujimoto and Murray 1970; Takeda and Hoshino 1975; Takeda 1976) and in man (Takeda 1972; Paran et al. 1975). The observations so far reported suggest that differences in structure are related to species specificity, the localization of the bud in lingual epithelium (Beidler 1969; Murray 1971, 1973; Mattern and Paran 1974) or other factors acting on the taste bud in the oral cavity.

Cell types constituting the taste bud have been reported by Farbman (1965a, b), Murray and Murray (1967) and Murray et al. (1969) and their functions were described by Mattern and Paran (1974), Para and Mattern (1975), Taked a (1977) and Farbman (1980). Other authors have studied the mechanism of replacement or regeneration of bud cells (B eidler and S mallman 1965; Farbman 1965b, 1980; Takeda 1977) and the mode of taste stimulus perception related to the taste pore region (A datia and Gehring 1971; Paran and Mattern 1975; Schiffman 1986).

The development of taste buds in lingual epithelium has also been investigated (Beidler and S mall ma $\mathrm{n}$ 1965; Fujimoto and Murray 1970; Taked a 1976; Farbman 1980) and the results suggest that both the time and site of bud origin are initiated by contact of epithelial cells with a nerve fibre.

The analysis and comparison of the findings made on the structure, function and origin of cells comprising the taste bud have shown that there are still questions to be answered. The objective of this study, as well as of the previous ones ( $\mathrm{Tich}$ y 1992a, b), has been to contribute to a discussion on the ultrastructure of taste buds in the early postnatal period because it is believed that this stage of ontogeny is important for the understanding of the problem.

\section{Materials and Methods}

Samples of circumvallate papillae were collected from the tongues of 3 kittens one day after birth. They were immediately fixed in $300 \mathrm{mmol} / \mathrm{l}$ glutaraldehyde solution in $100 \mathrm{mmol} / \mathrm{l}$ phosphate buffer for $4 \mathrm{~h}$. The tissue was subsequently washed in four changes of phosphate buffer $(100 \mathrm{mmol} / \mathrm{l})$ and postfixed in $40 \mathrm{mmol} / 1 \mathrm{OsO}_{4}$ in $100 \mathrm{mmol} / \mathrm{l}$ phosphate buffer for $1 \mathrm{~h}$. After dehydration in a graded acetone series $(0.25,0.50,0.75$ and 1.00 $\mathrm{mmol} / \mathrm{l}$ ), the samples were embedded in Durcupan ACM and polymerized at $60^{\circ} \mathrm{C}$ for 3 days. Fixation, dehydration and embedding were carried out at room temperature; $\mathrm{pH}$ of the buffered solutions was maintained at 7.4 to 7.42 .

Semithin sections $(1 \mu \mathrm{m})$ were stained with a 1:1 mixture of methylene blue and Azure II on a plate $50^{\circ} \mathrm{C}$ warm for $1 \mathrm{~min}$.

Ultrathin sections were cut on an Ultracut Reichert-Jung ultramicrotome, stained on grids (MESH 100) with uranyl acetate and lead citrate and examined and photograped in a Tesla BS 500 electron microscope. 


\section{Results}

Taste buds in the epithelium of circumvallate papillae in one-day-old kitten were elongated to spindle-shaped structures. In some of them, the apical parts were wider than the basal ones.

The taste pore presented as a narrow depression of varying depth. At the opening, desquamated epithelium often bulged making the taste bud appear even deeper. The space under desquamating epithelial cells was filled with transparent, finely filamentous material.

The feline taste buds were composed of three cell types: dark, light and receptor cells. All the cells were spindleshaped and extended from the bud base to the gustatory pore. The apical portions of cells in the region below the pore were connected with numerous desmosomes (Plate X, Fig. 3). All three cell types were in contact with intragemmal nerve fibres. Relatively thick fibres could be observed at the bud periphery close to the gustatory pore (Plate X, Fig. 3).

Dark cells (type I cells) were slimmer than the other cells of the taste bud.At the bud periphery, these cells were arranged in two or three tiers, with only the upper tier reaching the pore. The nuclei had an elongated, irregularly lobular shape and usually contained nucleoli of reticular type. Chromatin, in large aggregates, was located near the nuclear envelope (Plates IX, X, XI, Figs 2, 4, 5 and 6).

The cytoplasm included a large quantity of granular ER, numerous thick bundles of filaments located perinuclearly and frequent aggregates of glycogen inclusions particularly in cells at the bud periphery (Fig. 4). The Golgi complex was seen in the vicinity of the nucleus together with most of the mitochondria. These were oval or elongated in shape and had cristae mitochondriales (Plate IX, Fig. 1).

The apical portions of the dark cells located in the central area of the bud were extended towards the taste pore and terminated there with slim, irregular projections. Typical microvilli were not formed and the irregularly shaped projections did not reach the epithelial surface. The cytoplasm of this portion contained fine bundles of filaments with different orientation, a low number of vacuoles and, occasionally, dark granules about $100 \mathrm{~nm}$ in size. In the pore, regions of dark matter occurred rarely while small transparent vesicles (200 to 300 $\mathrm{nm}$ ) and finely particulate or filamentous material was more frequent.

Cells of this type were in close contact with intragemmal nerve fibres in an arrangement very similar to Schwann's sheath. However, no structures with features characteristic of synaptic junction were observed. On rare occasions, thick nerve fibres showed minute vesicles resembling synaptic vesicles.

The dark cells were connected to perigemmal, light and receptor cells by numerous bridges of desmosome type or by interdigitation in both the basal and apical portions of the taste bud (Figs 3, 4 and 5).

Light cells (type II cells) were characterized by large amounts of agranular ER in the cytoplasm and by a nucleus with a low amount of chromatin. Similarly to the dark cells, they extended from the base of the bud to its gustatory pore, penetrating into it with terminal processes. The nuclei were generally oval and showed minor karyolemma invaginations. Small clusters of chromatin were scattered in the karyoplasm. Heterochromatin formed occasional aggregates located immediately under the nuclear membrane. One or two nucleoli of reticular type were a regular finding (Figs 1, 2, 4 and 5).

The cytoplasm contained a high number of minute tramsparent vesicles (100 to $150 \mathrm{~nm}$ ) and numerous vesicles of agranular ER located above the nucleus (Figs 1, 2 and 3). In the same area, small spherical or ovoid mitochondria, infrequent clusters of glycogen granules 
and occasional lysosomes were also found. The Golgi complex, situated above the nucleus, was well developed and included two or three Golgi fields. (Fig. 1). Numerous thick bundles of filaments were located usually close to the nucleus (Fig. 5). The apical cytoplasm contained filaments only occasionally. The terminal part of the cell extended into the gustatory pore by means of irregular projections which, as also seen in the dark cells, did not come to level with the epithelial surface.

The light cells were connected, through numerous desmosomes, with both the dark and receptor cells (Figs 3, 4 and 5). Connection with nerve fibres occurred in the basal part of the bud over a relatively large area. The nerve fibre, however, never entered the cytoplasm to form a „mesaxon“. In the axoplasm of some fibres there were small light vesicles.

Receptor cells (type III. cells) were similar to the light cells in both appearance and localization but differed in a higher content of chromatin usually accumulated immediately under the nuclear membrane. Small clusters of heterochromatin were scattered in the karyoplasm. The nucleolus was of reticular type (Fig. 5). The nuclear surface in these cells was often folded into shallow invaginations (Fig. 5).

The cytoplasm included numerous cisternae of the granular ER, a small Golgi complex located near the nucleus and ovoid or spherical mitochondria. Numerous thick bundles of filaments were apparent in the perinuclear cytoplasm (Figs 4 and 5) but were seen only occasionally in the apical regions of the cells.

The area of contact between a receptor cell and a nerve fibre, and the protoplasm of the receptor cell near its contact with either a dark or a light cell showed transparent vesicles, about $100 \mathrm{~nm}$ in size, and vesicles with dark content of about the same size. These two structures, however, were seen in the cytoplasm only singly and on rare occasions (Figs 4 and 5).

The way of contact between receptor cells and nerve fibres was similar to that seen in the light cells.

Intergemmal nerve fibres were frequently found in the basal part of the taste bud (Fig. 6). The central area largely showed thin nerve fibres while, in the peripheral and apical regions, the fibres were thicker (Figs 2 and 3). The thin fibres included neurotubules, occasional mitochondria and a low number of filaments; the thick fibres had numerous mitochondria and vesicles 40 to $60 \mathrm{~nm}$ in size.

\section{Discussion}

The frequency and occurrence of each cell type in the taste buds on circumvallate papillae in one-day-old kittens is in agreement with the findings made in sheep and pigs ( T i c h ý 1992a, b).

Differences were found in the bud shape, which was elongated or spindle-like, in the appearance of the taste pore and partly also in the organelles found in the light, dark and receptor cells. As appears from many studies ( $\mathrm{S} \mathrm{mith}$ and Marcarian 1968; B ow man and Combe 1969; Murray 1973; Mattern and Paran 1974; Paran and Mattern 1975), the differences in the structure of buds are species-specific. The bud structure is also related to the localization of the bud on circumvallate, fungiform or filiform papillae and to the frequency and intensity of mechanical, physical and chemical factors in the oral cavity (Takeda and Hoshino 1975).

All these facts are also likely to play a role in the development of taste buds in the kitten. The porus gustatorius is formed similarly to that in the lamb (Tich ý 1992a) but the terminal processes of cells did not come up to the epithelial surface of the bud. In comparison with the findings made in piglets ( Tich ý 1992b), dark matter in the pore was seen in the same or lower quantity and secretory granules with dark content occurred only occasional- 
ly in type I cells. These differences can be explained by (i) a higher exposure of taste buds on the circumvallate papillae of kittens than on those of lambs ( T i ch ý 1992a) or (ii) in the period under study the process of differentiation is not completed or (iii) the structural characteristics are species-specific. It is open to question if the absence or minimal presence of dark extracellular substance in the porus gustatorius which, according to some authors ( Janke 1972) takes part in the perception of taste stimuli, is a species-specific characteristic or a feature indicating that the substance undergoes replacement by another substance. The results obtained from our previous studies in lambs and piglets ( Ti c hy 1 1992a, b) and from this study in kittens suggest that the amount of dark substance in the taste bud depends on the species observed.

The low amount of dark substance in the porus gustatorius is closely related to the occasional occurrence of dark granules in the apical cytoplasm of type I cells. The amount of filaments in the apical regions of the dark cells is also very low, which is different from the situations found in lambs and piglets ( $\mathrm{T}$ i $\mathrm{c}$ ý $1992 \mathrm{a}, \mathrm{b}$ ). It is possible, however, that at the later stages of ontogeny this disproportion will be „,corrected“ because the high amount of granular ER implies high synthetic activity of these cells. Similarly to the pig ( Ti c hy 1992b), the peripheries of the feline taste buds show cells, arranged in tiers, with high content of glycogen inclusions in the cytoplasm. These are regarded as immature dark cells described by some authors as peripheral cells arising from perigemmal cells (F a r b m a n 1965a).

The microvilli, which are typical of the terminal parts of type I cells in adult animals ( $\mathrm{M} \mathrm{u} \mathrm{r}$ ray 1973; Paran et al. 1975; Takeda and Hoshino; Takeda 1977), were absent in feline taste buds, which was in agreement with our previous findings in lambs and piglets (Tich ý 1992a, b). It is suggested that they will develop at later stages.

The relation of dark cells to intragemmal nerve fibres was identical with that seen in lambs and piglets (Tichý 1992a, b).

The function of light cells in the taste bud has not yet been fully understood. These cells were first considered to function as taste receptors (Murra y 1969), then as ,mediators“ between taste stimuli and the true receptor (Farbman and Yonkers 1971), later were regarded as secretory cells (Paran et al. 1975) and eventually as a terminal stage in the evolution of the taste bud cell population (F a rb ma n 1980). With respect to these views, the large amount of agranular ER in the supranuclear cytoplasm of the centrally located light cells appears to be an interesting finding. The arrangement is reminiscent of the ER but without ribosomes on the membranes of its cisternae. It can be speculated that these cells have ceased synthesizing proteins and the observed arrangement of the ER remains as an indication of their previous activity. This would support the view held by F a r b m a n (1980). On the other hand, this organelle arrangement has not been detected in the light cells of taste buds either in lambs or in piglets, which suggests the possibility of a species-specific structure in this cell type.

The light cells were observed to be in contact with nerve fibres some of which had minute vesicles in the axoplasm and thus could be regarded as nerve endings. Whether these vesicles were synaptic vesicles, such as those described by Pa r a n et al. (1975), could not be decided. The fact that the contact of intragemmal nerve fibres with light cells was similar to that seen in the receptor cells supports the view held by F a r b m a n (1980) that, in the development of the taste bud, the light cells evolve after the receptor cells. It is believed that the relationships between the cell types involved in the bud can be understood from the system, character and connection of intragemmal nerve fibres, as reported by Take da (1977).

In the kitten, the receptor cells contained a higher amount of filaments located around the nucleus than the corresponding cells in lambs and piglets. This is in agreement with the observations of several authors (Murray et al. 1969; Murray 1973) who suggested that the receptor cells were derived from epithelial cells. On the other hand, because of the occur- 
rence of vesicles with dark substance in the cytoplasm, the receptor cells can be regarded as derivatives of nerve tissue ( $\mathrm{T}$ a ke d a 1977; F a r b m a n 1980) similarly to the cells of some other receptors (PáC 1984). Because these structures are present in the area of contact between the receptor cell and nerve ending, their involvement in transmission of stimuli seems obvious. In kittens, lambs and piglets, dark vesicles are observed in type III cells only occasionally and not in aggregates as described by some authors ( Takeda and Hoshino 1975; T a k e d a 1977) in adult mammals. It is possible that the number of dark vesicles will increase with a growing role of the taste bud later in life.

In the receptor cells, contacts with nerve fibres were similar to those seen in the light cells and this situation in kittens was in agreement with our earlier observations in lambs and piglets ( Ti ch ý 1992a, b). However, this study did not reveal the desmosome-like connection between receptor cells and nerve fibres seen in piglets ( $\mathrm{T} i \mathrm{ch}$ ý 1992b).

The differences in the structure of taste buds and in the ultrastructure of cell types observed in this and previous studies, as compared with the data reported in the literature for adult animals, can be explained by an incomplete process of differentiation in early postnatal periods.

\section{Ultrastrukturạ chutových pohárků u kočky po narození}

Na hrazených papilách, odebraných z jazyků tři jednodenních kotat, byla sledována ultrastruktura chutových pohárkủ. Zaměrili jsme se na výskyt, lokalizaci a organelovou výbavu jednotlivých typủ buněk pohárku, na utváření porus gustatorius, na přítomnost intragemálních nervových vláken a charakter jejich kontaktủ s buñkami pohárku.

Zjistili jsme, že v době narození jsou v chutových pohárcích kotěte zastoupeny buñky tmavé, světlé i receptorové. Všechny typy buněk obsahují v cytoplasmě značné množství filament. Sekretorická granula se v tmavých buňkách vyskytují toliko sporadicky, stejně jako okrsky tmavé substance $\mathrm{v}$ chutovém póru. Tmavé i světlé vesikuly jsou v cytoplasmě receptorových buněk zastoupeny pouze ojediněle. Apikální úseky buněk pohárku nejsou členěny v mikroklky a nedosahují úrovně povrchu epitelu. Intragemální nervová vlákna jsou málo početná, avšak vstupují do kontaktů se všemi typy buněk pohárku.

\section{Ультраструктура вкусовых луковиц кошки послө рождөния}

На желобоватых сосочках, отобранных на языках трех односуточных котят, исследовали ультраструктуру вкусовых луковиц. Нами было направлено внимание на наличие, определение места и органеллы отдельных типов клеток луковицы, на формирование вкусового отвсрстия, на наличие интрагемальных нервных волокон и характер их контактов склетками луковицы.

Нами было установлено, что в период рождения во вкусовых луковицах котят представлены темные, светлые и рецепторные клетки. Все типы клеток содержат вцитоплазме значительное количество нитей. Секреторная гранула в темных клетках встречается спорадически, то же самое касается участком темного характера во вкусовом отверстии. Темные и светлые пузырьки в цитоплазме рецепторных клеток представлены лишь в единичных случаях. Верхушечные участки клеток луковицы не разделены на микроворсинки и не достигают уровня поверхности эпителия. Интрагемальные нервные болокна не особо численны, однако они входят в контак со всеми типами клеток луковицы.

\section{References}

ADATIA, A. K.-GEHRING, E. N.: Proprioreceptive innervation of the tongue. J. Anat., 110, 1971: 215-220. BEIDLER, J. M.: Innervation of rat fungiform papilla. In: Olfaction and taste 3, Pfaffman (ed.), New York: Rockefeller Univ. Press. 1969: 352-369.

BEIDLER, J. M.-SMALLMAN, R. L.: Renewal of cells within taste buds. J. Cell Biol., 27, 1965: 263-272. 
BOWMAN, J. P.-COMBS, C. M.: The cerebrocortical projection of hypoglossal afferents. Exp. Neurol., 23, 1969: 291-301.

FARBMAN, A. I.: Fine structure of the taste bud. J. Ultrastruct. Res., 12, 1965a: 328-350.

FARBMAN, A. I.: Electron microscope study of the developing taste bud in rat fungiform papilla. Develop. Biol., 11, 1965b: 110-135.

FARBMAN, A. I.: Renewal of taste-bud cells in rat circumvallate papillae. Cell Tissue Kinet., 13, 1980: 349-357.

FARBMAN, A. I.-YONKERS, J. D.: Fine structure of the taste bud in the mud puppy. Necturus maculosus. Am. J. Anat., 131, 1971: 353-370.

FUJIMOTO, S.-MURRAY, R. G.: Fine structure of degeneration and regeneration in denervated rabbit vallate taste buds. Anat. Rec., 168, 1970: 393-414.

JAHNKE, K.: Der feinstrukturelle Nachweis der Acetylcholinesterase-Aktivität in den Geschmacksknospen der Papillae foliatae des Kaninchens. Arch. Klin. exp. Ohr., Nas., u. Kahlkopf-Heilk. 203, 1972: 125-152.

MATTERN, C. F. T.-PARAN, N.: Evidence of a contractile mechanism in the taste bud of the mouse fungiform papilla. Exp. Neurol., 44, 1974, 461-469.

MURRAY, R. G.: Cell types in rabbit taste buds. In: Olfaction and taste III, Pfaffman (ed.), New York, Rockefeller Univ. Press. 1969: 331-344.

MURRAY, R. G.: Ultrastructure of taste receptors. In: Handbook of sensory physiology, vol. IV Chemical senses, part 2 Taste. Beidler (ed.), Berlin-Heidelberg-New York: Springer, 1971: 31-50.

MURRAY, R. G.: The structure of taste buds. In: Ultrastructure of sensory organ, vol. 1, Friedman (ed.), Amsterdam: North Holland, 1973: 1-81.

MURRAY, R. G.-MURRAY, A.: Fine structure of taste buds of rabbit foliate papillae. J. Ultrastruct. Res., 19, 1967: 327-353.

MURRAY, R. G.-MURRAY, A.-FUJIMOTO, S.: Fine structure of gustatory cells in rabbit taste buds. J. Ultrastruct. Res., 27, 1969: 444-461.

MURRAY, R. G.-MURRAY, A.-HELLEKANT, G.: Fine structure of taste buds of rat fungiform papillae. In: Proceedings of the Fourth International Symposium on Olfaction and Taste. Schneider, ed. Stuttgart: Wissenschaftliche Verlagsgesellschaft MBH 1972.

PÁĆ, L.: Contribution to ontogenesis of Merkel cells. Z. mikrosk.-anat. Forsch., 98, 1984: 36-48.

PARAN, N.-MATTERN, C.F.T.: The distribution of acetylcholinesterase in buds of the rat vallate papilla as determined by electron microscope histochemistry. J. comp. Neurol., 159, 1975: $29-44$.

PARAN, N.-MATTERN, C. F. T.-HENKIN, R. I.: Ultrastructure of the taste bud of the human fungiform papilla. Cell. Tiss. Res., 161, 1975: 1-10.

SCHIFFMAN, S. S.: Recent insights into the mechanism of taste transduction and modulation. Food Chemistry E 3648, vol. 21, No 4, Elsevier Applied Sci., 1986: 259-263.

SMITH, R. D.-MARCARIAN, H. Q.: Centripetal localization of tooth and tongue tension receptors J. Dent. Res., 47, 1968: 616-621.

TAKEDA, M.: Fine structure of developing taste buds in human fetal circumvallate papillae (in Japanese with English summary). Acta Anat. Nippon., 47, 1972: 325-337.

TAKEDA, M.: An electron microscopic study on the innervation in the taste buds of the mouse circumvallate papillae. Arch. Histol. Jap., 39 1976: 257-269.

TAKEDA, M.: Uptake of 5-hydroxytryptophan by gustatory cells in the mouse taste bud. Arch. Histol. Jap., 40, 1977: 243-250.

TAKEDA, M.-HOSHINO, T.: Fine structure of taste buds in the rat. Arch. Histol. Jap., 37, 1975: 395-413.

TICHÝ, F.: The ultrastructure of taste buds in the newborn lamb. Acta vet. Brno, 61, 1992a: 83-91.

TICHY, F.: The ultrastructure of taste buds in the newborn pig. Acta vet. Brno, 61, 1992a: 171-177. 
Tichý F.: The ultrastructure of taste buds... pp. 49-54

Plate IX.

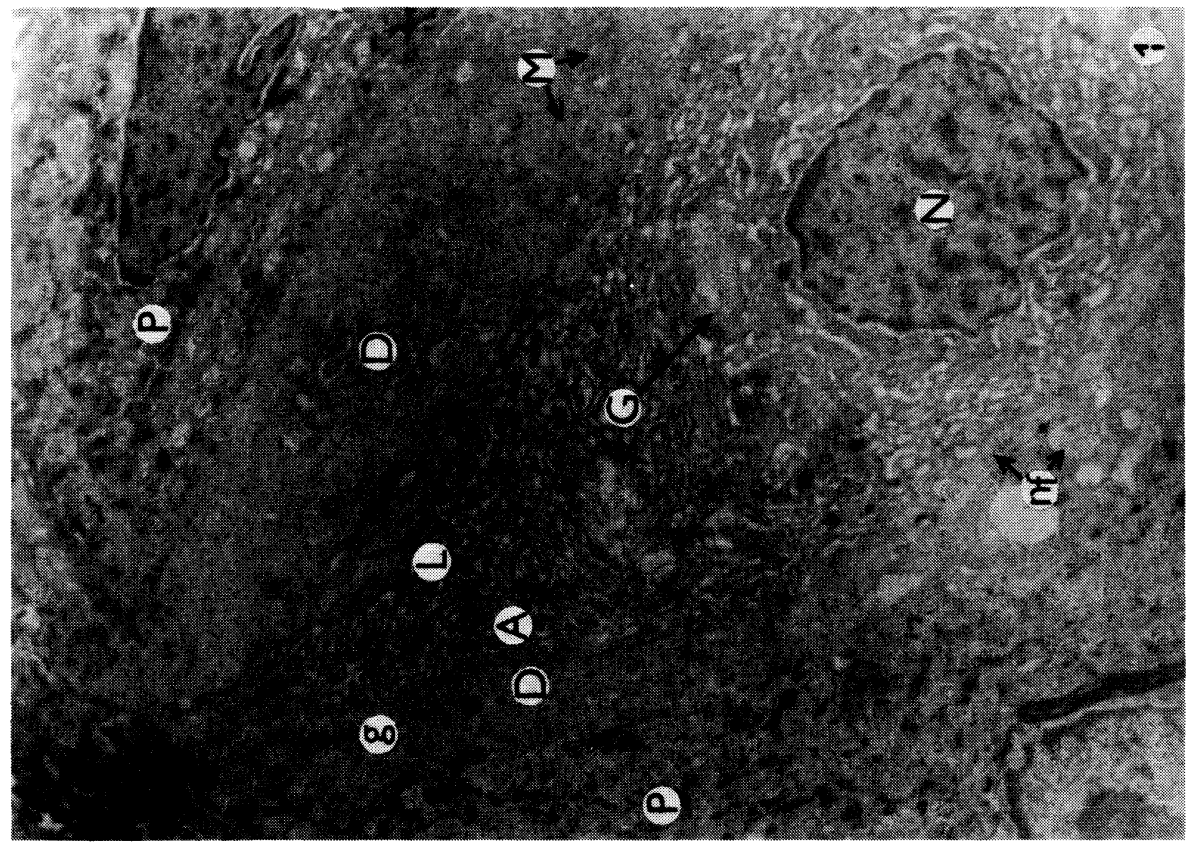

Fig. 1: Apical portion of a feline taste bud. Dark cells (D), light cells (L), perigemmal cells (P). Dark granules (g) and mitochondria (M) in the cytoplasm of a dark cell. The Golgi complex (G) above the nucleus $(\mathrm{N})$ and numerous cisternae of agranular endoplasmic reticulum (A). Intragemmal nerve fibres (nf). $\times 8000$.

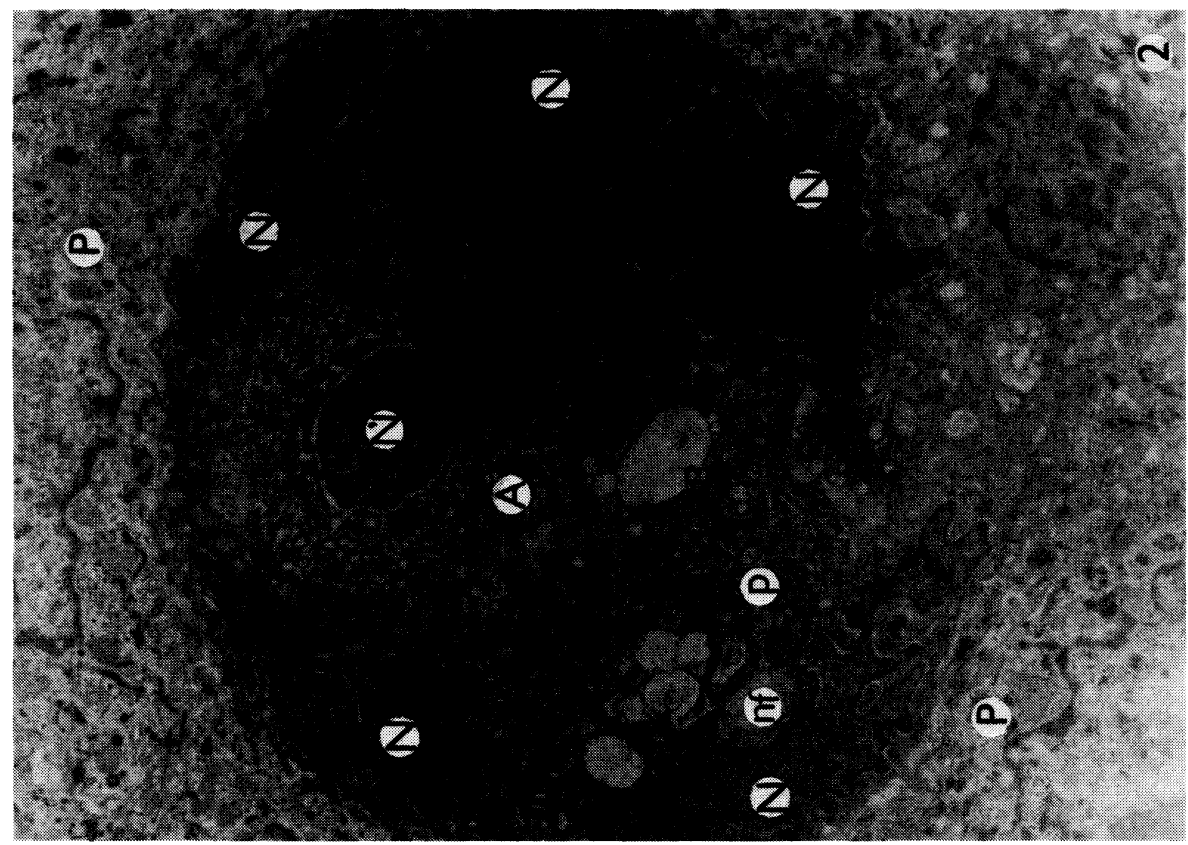

Fig. 2: Cross section through the central part of a feline taste bud. Nuclei of dark cells $(\mathrm{N})$ at the bud periphery. Nuclei of light cells (N') surrounded by cisternae of agranular endoplasmic reticulum (A). Intragemmal nerve fibres (nf). Pseudomyelin structure (p). Perigemmal cells (P). $\times 8000$. 
Plate X.

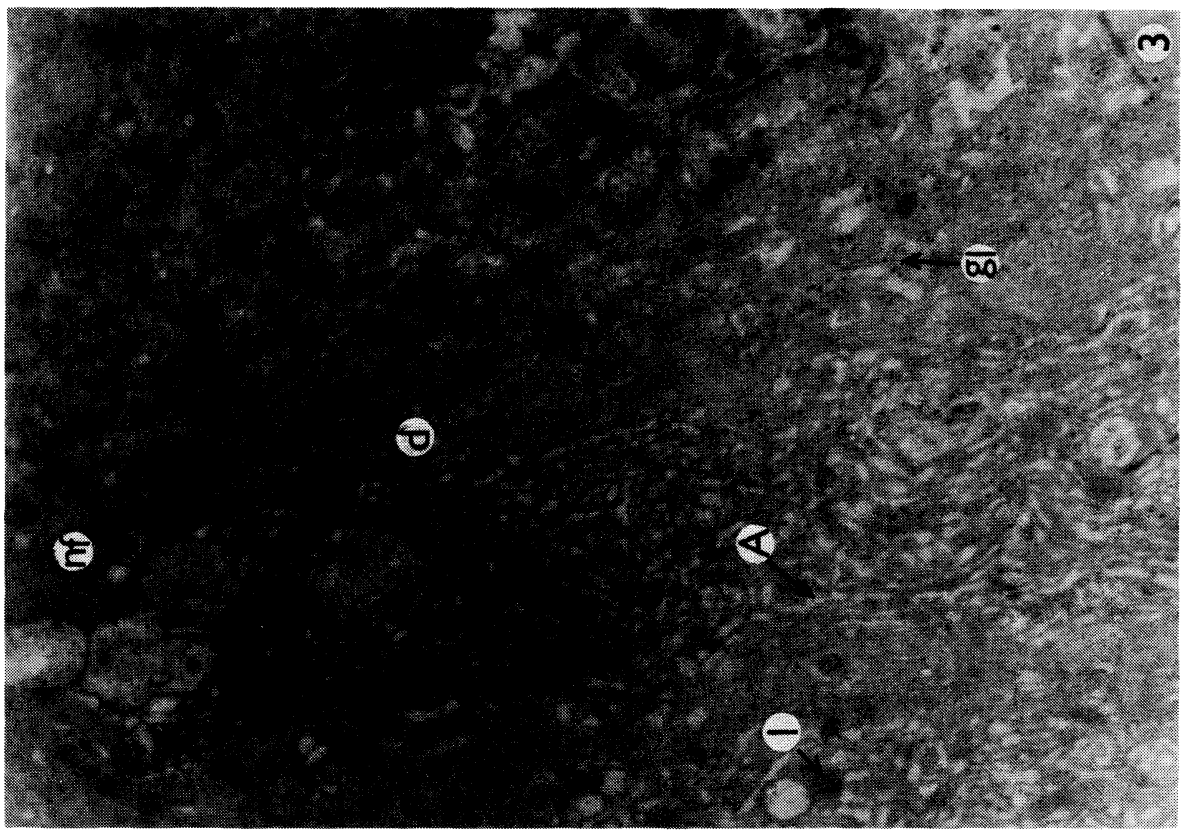

Fig. 3: Group of nerve fibres (nf) in the apical portion of a feline taste bud. Cisternae of agranular endoplasmic reticulum (A) and lysosomes (1) in the cytoplasm of a light cell. Aggregates of glycogen inclusions (gl) in a dark cell. Numerous desmosomes (d) between a perigemmal and the dark cell. $\times 16000$.

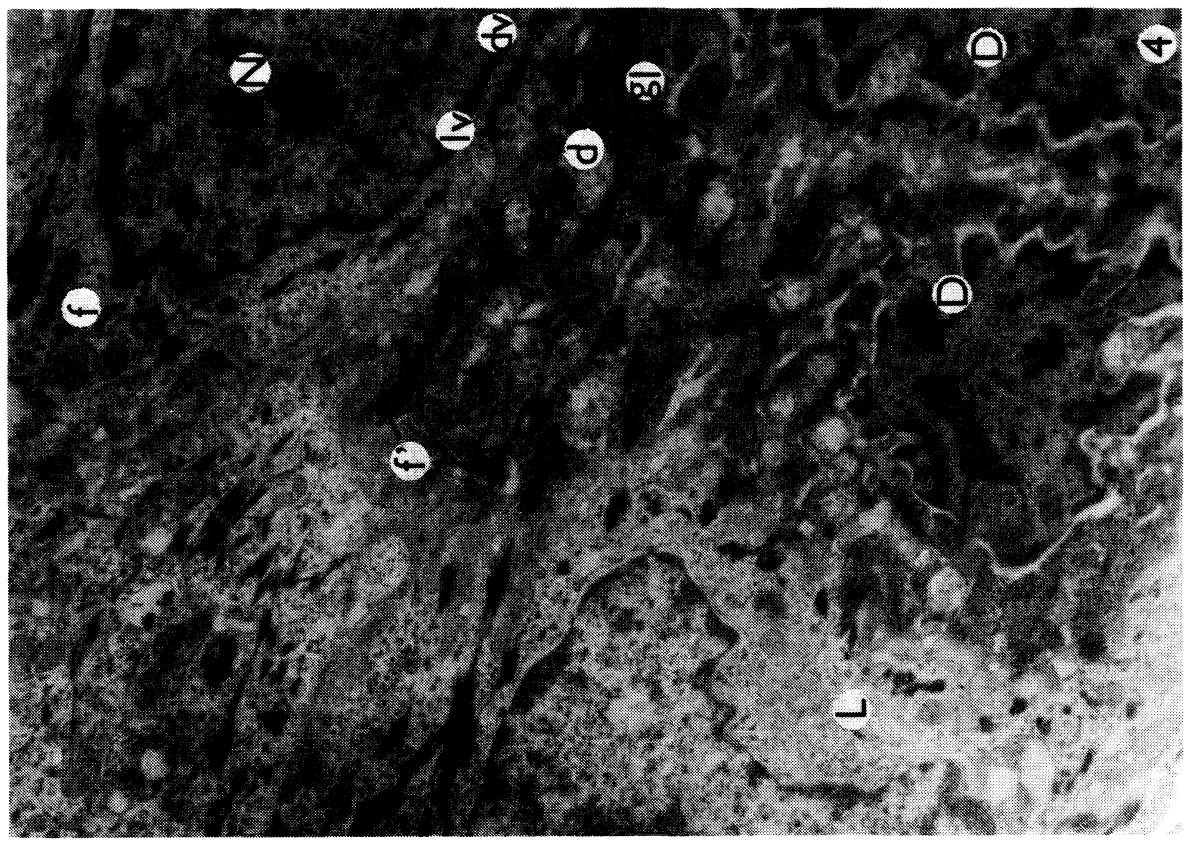

Fig. 4: Cells in the central part of a feline taste bud. Light cell (L), dark cells (D) and the nucleus of a receptor cell $(\mathrm{N})$ with accumulated bundles of filaments (f). Glycogen inclusions ( $\mathrm{gl}$ ) and filaments (f') in the cytoplasm of a dark cell. Desmosome (d) between the receptor cell and one dark cell. Light (lv) and dark (dv) vesicles in the cytoplasm of the receptor cell. $\times 12000$. 


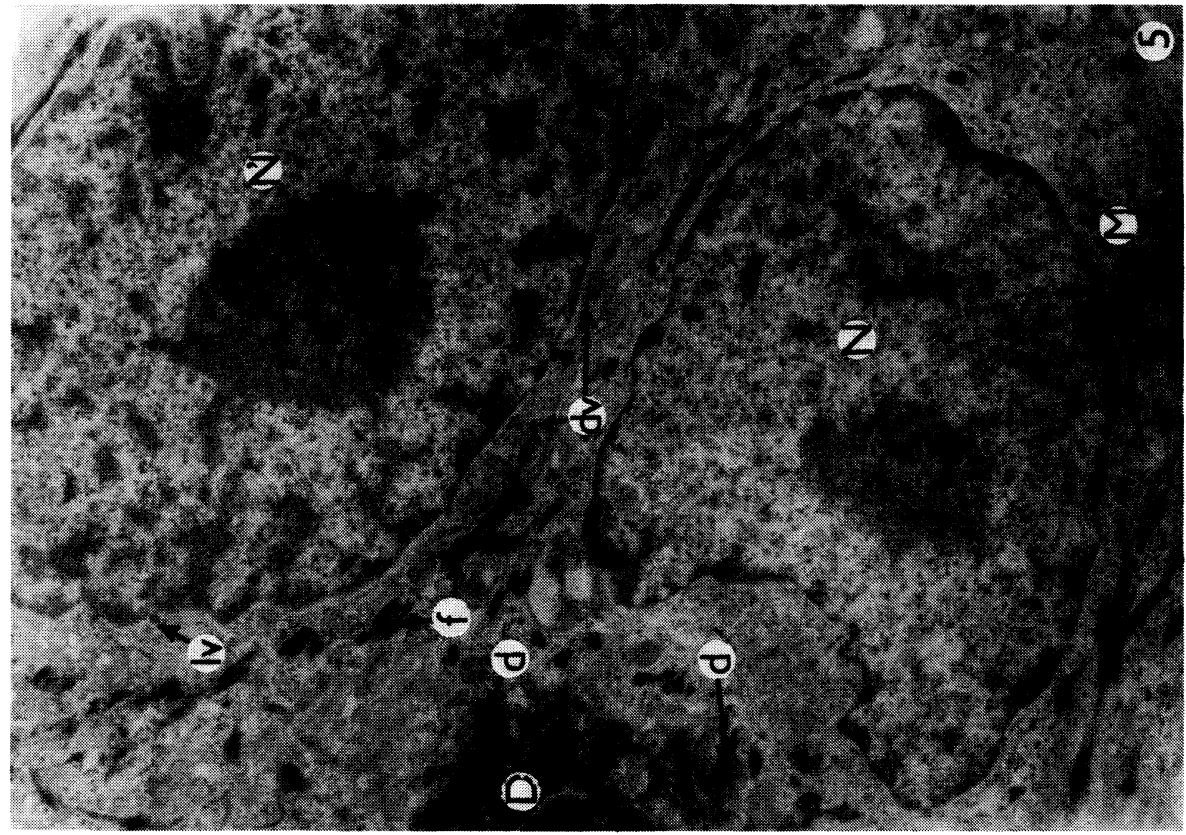

Fig. 5: Nucleus of a light cell (N) and that of a receptor cell (N') in the central part of a feline taste bud. Dark cell (D) connected by desmosomes (d) with the light cell. Numerous bundles of filaments (f), light (lv) and dark (dv) vesicles in the cytoplasm of the receptor cell. Mitochondria (M) in the cytoplasm of the light cell. $\times 12000$.

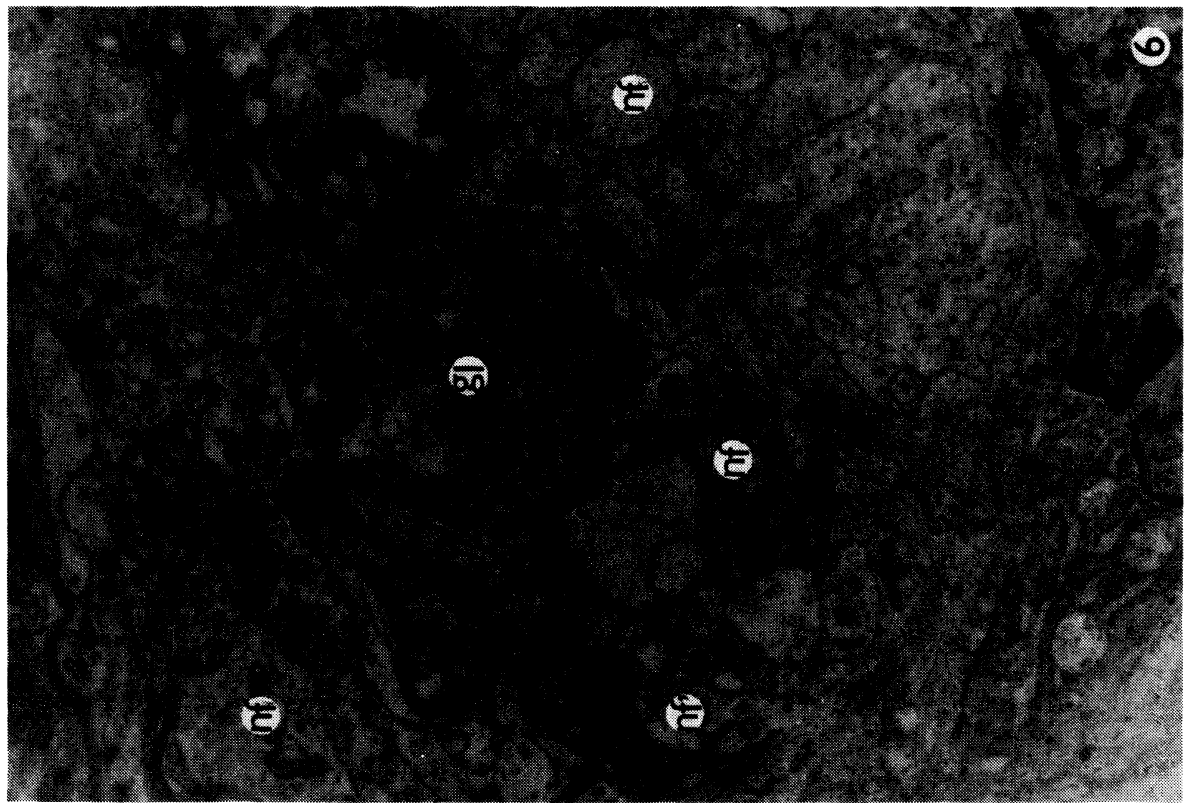

Fig. 6: Numerous nerve fibres (nf) in the basal part of a feline taste bud. Glycogen inclusions (gl) in the cytoplasm of a light cell. Nerve fibre (nf) in the cytoplasm of a dark cell. $\times 16000$. 